\title{
Emakoiden liemirehujen koostumus ja sen vaihtelu
}

\author{
Kirsi Partanen ${ }^{1)}$, Maija Yliaho ${ }^{2)}$ ja Johanna Sippola ${ }^{2)}$ \\ 1) MTT, Kotieläintuotannon tutkimus, Tervamäentie 179, 05840 Hyvinkää, kirsi.partanen@mtt.fi \\ ${ }^{2)}$ ProAgria Etelä-Pohjanmaa, Huhtalantie 2, 60220 Seinäjoki, maija.yliaho@proagria.fi, johan- \\ na.sippola@proagria.fi
}

\section{Tiivistelmä}

Emakoita ruokitaan yhä useammin liemellä, ja tiloilla on käytössä useita erimerkkisiä liemiruokintalaitteita. Liemiruokintalaitteet voidaan jakaa toimintaperiaatteen mukaan kahteen ryhmään: niihin joissa on aina jäännösrehua putkistossa ja niihin jotka tyhjäävät putkiston rehusta ruokintojen välillä joko veden tai höyryn avulla. Liemiruokinnan etuna on mahdollisuus hyödyntää joustavasti nestemäisiä sivutuoterehuja, erilaisia viljoja ja muita kuivia rehuaineita niiden saatavuuden ja hintojen vaihtelun mukaan. Liemirehuseoksia tehdään myös kuivista rehuista ja vedestä. Liemiruokintatutkimus on painottunut erilaisten sivutuoterehujen rehuarvon ja tuotantovaikutusten määrittämiseen ja liemirehujen mikrobikäymisen tutkimiseen. Ruokintalaitteiden toimivuudesta ja liemirehuseosten laadun tasaisuuteen vaikuttavista tekijöistä löytyy kuitenkin niukasti julkaistua tietoa. Käytännössä on usein nähty, ettei kaukaloon tuleva rehu ole aina yhtä paksua ja erityisesti kivennäisten epäillään lajittuvan rehunjakolinjastossa. Liemirehun koostumusvaihteluun voivat vaikuttaa sivutuoteliemien koostumuksen vaihtelu, rehukomponenttien fysikaaliset ominaisuudet ja ruokintalaitteen säädöt ja linjaston rakenne.

Tavoitteenamme oli selvittää tiloilta kerättyjä näytteitä analysoimalla, miten hyvin tiineiden ja imettävien emakoiden saama liemirehu vastaava seoksen optimoitua ja koneelle laitettua reseptiä, ja vaikuttaako liemiruokkijan toimintaperiaate sikojen saaman liemen koostumukseen.

Tutkimuksessa oli mukana 12 eteläpohjalaista tilaa, missä emakoiden liemirehut sekoitettiin vähintään kahdesta rehukomponentista. Tiloilla oli eri valmistajien liemiruokkijoita (Pellon Group, Big Dutchman, Howema, Weda ja Schauer), jotka jaettiin toimintaperiaatteen mukaan kahteen ryhmään: laitteisiin, joissa oli aina jäännösrehua putkistossa ja niihin jotka tyhjäävät putkiston rehusta ruokintojen välillä. Syksyn 2010 tilakäynneillä kerättiin koontinäytteitä tiineys- ja imetysrehuista. Osalla tiloista otettiin myös venttiilinäytteitä, koska liemi oli jo silmämääräisesti havaiten vetistä linjaston lopussa. Talven 2011 tilakierroksella kaikkien tilojen näytteet otettiin tiineiden ja imettävien emakoiden ruokintapiirin alusta, keskeltä ja lopusta. Jäännösrehullista laitteista näytteet otettiin jakoputken päästä venttiilin päästäessä rehua kaukaloon. Vesipesulinjastoissa velli ei tullut tasaisena massana kaukaloon, vaan usein ensin tuli vetisempää lientä. Siksi näytteet päädyttiin ottamaan kaukalosta perusteellisen sekoittamisen jälkeen.

Koontinäytteistä tehtyjen rehuanalyysien perusteella tiineiden ja imettävien emakoiden liemet olivat koostumukseltaan erilaisia, ja pääsääntöisesti emakot saivat tuotantovaiheeseen sopivaa lientä. Jäännösrehuputkistojen liemissä oli terve maitohappokäyminen ja hieman alempi pH kuin pestävien putkistojen liemissä.

Jäännösrehulaitteissa liemen kuiva-ainepitoisuus vaihteli vähän linjaston eri osissa ja oli melko lähellä tavoitetta. Sen sijaan putkiston tyhjäävien laitteiden liemen kuiva-ainepitoisuus laski linjaston loppua kohti, ja mitatun ja tavoitellun kuiva-ainepitoisuuden välinen ero suureni. Tiloilla ongelma oli hyvin tiedostettu ja koneen jälkiä korjattiin jakamalla emakoille lisärehua käsin. Venttiilinäytteiden analysointi osoitti, että liemen kuiva-aineen tuhka- ja valkuaispitoisuus pysyivät samanlaisina linjaston alussa ja lopussa. Kuiva-aineen fosforin, natriumin ja sinkin pitoisuuksissa ei myöskään havaittu eroja näytteenottopaikan suhteen. Kuiva-aineen kalsiumpitoisuus ja kalsiumin ja fosforin suhde kuitenkin pienenivät linjaston loppua kohti. Laskevan kuiva-ainepitoisuuden vuoksi vesipesulinjastojen loppupään liemissä oli tuorepainoa kohti vähemmän valkuaista ja kivennäisaineita kuin jäännösrehullisten laitteiden liemissä. Jostain syystä putkiston tyhjentävissä laitteissa rehua eteenpäin työntävä vesipatsas näytti sekoittuvan erilailla erilaisiin liemiin.

Tulosten perusteella emakoiden liemirehuseosten kuiva-ainepitoisuus vaihtelee rehunjakolinjaston eri osissa, ja vaihtelua on enemmän putkiston tyhjäävissä ja pesevissä kuin jäännösrehullisissa liemiruokintalaitteissa. Ravintoaineista erityisesti kalsium näyttää lajittuvan linjastossa, mikä voi johtaa emakoiden kannalta liian matalaan kalsiumin ja fosforin suhteeseen.

Asiasanat: liemiruokinta, emakot, vaihtelu 


\section{Johdanto}

Liemiruokinnassa siat ruokitaan vellimäisillä rehuseoksilla, joiden sekoitusta ja jakoa karsinoihin ohjataan ruokintalaitteiston tietokoneella. Liemiruokinnan etuna on tilojen mahdollisuus hyödyntää joustavasti nestemäisiä sivutuoterehuja, erilaisia viljoja ja muitakin kuivia rehuaineita niiden saatavuus ja hintojen vaihtelu huomioiden. Liemirehuseoksia tehdään myös kuivista rehuista ja vedestä. EFSA 2006 tekemän arvion mukaan sikojen liemiruokinta on yleisempää Suomessa kuin monissa muissa EU-maissa, ja Suomessa 60 \% kaikista sioista ja $20 \%$ emakoista ruokitaan liemirehulla.

Liemiruokintatutkimus on painottunut erilaisten sivutuoterehujen rehuarvon ja tuotantovaikutusten (esim. Valaja 1998, Siljander-Rasi \& Valaja 2008) ja liemirehujen mikrokäymisen tutkimiseen (esim. Plumes-Ferrer ym. 2005, Plumed-Ferrer ja von Wright 2011). Liemiruokintalaitteiden toimivuudesta ja liemirehuseosten lajittumiseen vaikuttavista tekijöistä löytyy niukasti julkaistua tietoa. Kanadalaisen tilaselvityksen mukaan liemirehuseosten kuiva-ainepitoisuus vaihtelee suuresti tilojen välillä ja tilan sisällä sekoitustankin ja ruokintalinjaston eri venttiilien välillä (Braun ja de Lange 2004). Käytännössä on usein nähty, ettei venttiililtä kaukaloon tuleva rehu ole aina yhtä paksua ruokintapiirin eri osissa ja erityisesti kivennäisten on epäilty lajittuvan rehunjakolinjastossa. Liemirehujen koostumusvaihteluun vaikuttavat useat tekijät, kuten sivutuoteliemien koostumusvaihtelu ja sen huomioiminen ruokinnassa ja rehukomponenttien ominaisuudet, kuten partikkelikoko, ominaispaino ja vedensidontakyky (Braun ja de Lange 2004, de Lange ym. 2006). Ruokintalaitteen säädöt, linjaston rakenne, rehuseoksen koostumus ja muhimisaika sekoituksen jälkeen vaikuttavat myös liemirehun virtausominaisuuksiin ja pumpattavuuteen (Cumby 1986). Liemiruokinnassa kuiva-aineen ja veden suhde voi vaihdella 1:1,5 - 1:4 välillä (Hurst ym. 2008, Missotten ym. 2010), mutta suositeltavinta on pitää kuiva-aineen ja veden suhde 1:2,5 - 1:3:n välillä.

Tämän tutkimuksen tavoitteena oli kartoittaa tiineiden ja imettävien emakoiden liemiruokinnan toteutusta tiloilla ja selvittää tiloilta kerättyjä näytteitä analysoimalla, miten hyvin tiineiden ja imettävien emakoiden saama liemirehu vastaava seoksen optimoitua ja koneelle laitettua reseptiä, ja vaikuttaako liemiruokkijan toimintaperiaate sikojen saaman liemen koostumukseen.

\section{Aineisto ja menetelmät}

Tutkimuksessa oli mukana 12 eteläpohjalaista porsastuotantotilaa, jotka valmistivat emakoiden liemirehuseokset käyttäen viljaa, sivutuoterehuja tai muita rehuaineita ja komponenttiruokintaan tarkoitettuja täydennysrehuja. Tiloilla oli seuraavien valmistajien liemiruokkijoita: Pellon Group, Big Dutchman, Howema, Weda ja Schauer. Ruokintalaitteet jaettiin toimintaperiaatteen mukaan kahteen ryhmään: 1) laitteet, joissa on aina jäännösrehua putkistossa ja 2) laitteet, jotka tyhjentävät putkiston ruokintojen välillä.

Ensimmäinen näytteenottokierros tehtiin tiloille syksyllä 2010. Tiineiden ja imettävien emakoiden rehuseoksista otettiin usean venttiilin näytteistä muodostettuja koontinäytteitä. Osalla tiloista otettiin myös venttiilinäytteitä, koska liemi oli jo silmämääräisesti havaiten vetistä linjaston lopussa. Talven 2011 toisella näytteenottokierroksella kaikkien tilojen näytteet otettiin tiineiden ja imettävien emakoiden ruokintapiirin alusta, keskeltä ja lopusta. Jäännösrehullista laitteista näytteet otettiin jakoputken päästä venttiilin päästäessä rehua kaukaloon. Vesipesulinjastoissa velli ei tullut tasaisena massana kaukaloon, vaan usein ensin tuli vetisempää lientä. Siksi näytteet päädyttiin ottamaan kaukalosta perusteellisen sekoittamisen jälkeen. Sekä koonti- että venttiilinäytteitä otettiin $1 \mathrm{l}$ /rehuseos ja näytteet pakastettiin mahdollisimman pian näytteenoton jälkeen ja toimitettiin analysoitavaksi jäisinä.

Näytteiden analysointia varten pakastetut näytteet sulatettiin ja sekoitettiin hyvin, ja niistä mitattiin pH ja määritettiin kuiva-ainepitoisuus lämpökaapissa $\left(105^{\circ} \mathrm{C}: s s a 20 \mathrm{~h}\right)$. Ensimmäisen näytteenottokierroksen venttiilikohtaisia näytteitä yhdistettiin koontinäytteiksi, ja kaikista koontinäytteistä määritettiin tuhka, raakavalkuainen, raakarasva ja raakakuitu AOAC:n (1990) mukaan ja maitohappopitoisuus Haackerin ym. (1983) mukaan. Toisen näytteenottokierroksen venttiilikohtaisista näytteistä määritettiin kuivaaine ja pH. Linjaston alku- ja loppupään venttiileiltä otetuista näytteistä määritettiin tuhka, raakavalkuainen (AOAC 1990) ja kivennäisaineista kalsium, fosfori, natrium ja sinkki ICP emissiospektrometrillä (Luh Huang ja Shulte 1985).

Tulokset analysointiin käyttäen SAS® 9,2 ohjelmistoa ja sekamallia, jossa oli tilan satunnainen ja rehuseoksen ja laitetyypin kiinteät vaikutukset ja näiden yhdysvaikutus. Venttiilinäytteiden osalta mallissa oli myös venttiilipaikan kiinteä vaikutus ja tämän yhdysvaikutukset rehuseoksen ja laitetyypin kanssa. 


\section{Tulokset ja tulosten tarkastelu}

Imettävien emakoiden rehuseoksissa oli enemmän tuhkaa, raakavalkuaista ja raakarasvaa ja vähemmän raakakuitua ja typettömiä uuteaineita kuin tiineiden emakoiden rehuseoksissa (taulukko 1), kuten emakoiden ruokintasuositusten mukaan pitääkin olla (MTT 2011). Tiineiden ja imettävien emakoiden rehuseosten ravintoainekoostumuksessa ei ollut eroja laitetyyppien välillä. Sen sijaan $\mathrm{pH}$ oli hieman matalampi jäännösrehullisissa kuin putkiston tyhjäävissä ruokintalaitteissa. Maitohapon pitoisuudessa (\% liemestä) oli rehuseoksen ja laitetyypin välillä yhdysvaikutus $(\mathrm{P}<0,05)$. Maitohappoa oli enemmän imetys- kuin tiineysrehuissa, ja rehuseoksen ja laitetyyppien välillä oli yhdysvaikutus (kuvio 1). Maitohapon pitoisuuteen vaikuttavat sekä rehuseoksissa käytetyt rehuaineet ja liemessä tapahtuva spontaani mikrobikäyminen. Sivutuoteliemissä, ohravalkuaisrehussa ja herassa on maitohappokäymisen seurauksena muodostunutta maitohappoa jo ennen niiden sekoittamista liemirehuksi. Jäännösrehullisissa laitteissa liemirehu käy putkistossa ruokintojen välillä, ja sekoittuu osaksi uutta rehuseosta, kun laite kierrättää rehua putkistossa ennen ruokintaa. Laitteistossa oleva toimii uudessa rehuerässä ymppinä ja liemirehun mikrobikoostumus stabiloituu muutaman viikon aikana ruokinnan aloittamisesta puhtaassa laitteistossa (Plumed-Ferrer ym. 2004).

Taulukko 1. Liemirehuseosten koontinäytteiden analysoitu koostumus rehuseoksen ja laitetyyppien mukaan.

\begin{tabular}{|c|c|c|c|c|c|c|}
\hline & \multicolumn{2}{|c|}{ Rehuseos } & \multirow[b]{2}{*}{$\mathrm{P}$} & \multicolumn{2}{|c|}{ Laitetyyppi } & \multirow[b]{2}{*}{$\mathrm{P}$} \\
\hline & Imettävät & Tiineet & & Jäännösrehu & Tyhjäävä & \\
\hline Kuiva-aine, \% & $23,7(1,0)$ & $23,4(1,0)$ & & $26,0(1,3)$ & $21,2(1,3)$ & $*$ \\
\hline Ravintoaineet, g/kg ka & & & & & & \\
\hline Tuhka & $62,1(2,8)$ & $52,6(2,8)$ & $* *$ & $57,0(3,5)$ & $57,7(3,6)$ & \\
\hline Raakavalkuainen & $201,5(3,0)$ & $174,2(2,9)$ & $* * *$ & $185,4(2,8)$ & $190,3(3,1)$ & \\
\hline Raakarasva & $50,4(4,1)$ & $33,6(4,1)$ & $* * *$ & $41,0(5,3)$ & $42,9(5,3)$ & \\
\hline Raakakuitu & $50,5(3,3)$ & $59,6(3,3)$ & * & $53,2(3,9)$ & $56,9(4,0)$ & \\
\hline Typettömät uuteaineet & $636,4(9,2)$ & $681,4(9,2)$ & $* * *$ & $665,3(12,1)$ & $652,5(12,2)$ & \\
\hline $\mathrm{pH}$ & 4,93 $(0,10)$ & $4,91(0,10)$ & & $4,72(0,14)$ & $5,12(0,14)$ & 0,07 \\
\hline
\end{tabular}

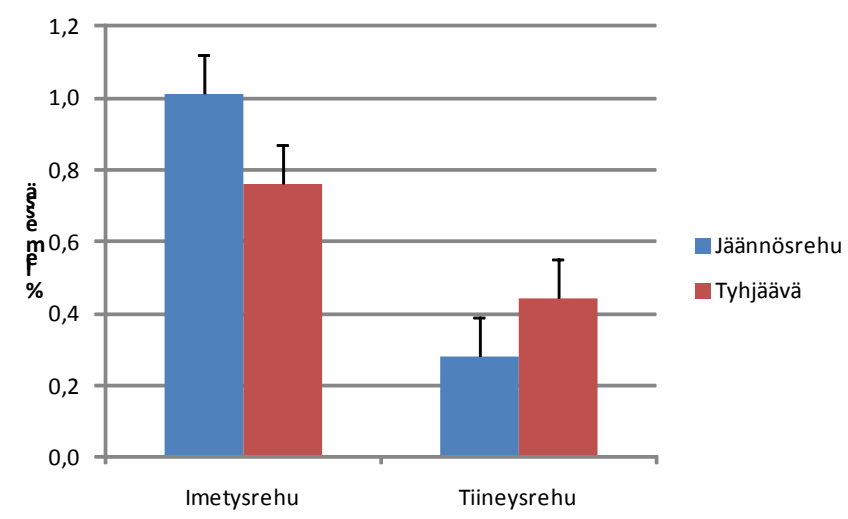

Kuvio 1. Liemirehuseosten koontinäytteiden maitohappopitoisuus.

Venttiilinäytteiden kuiva-ainepitoisuuden vaihtelua kuvaava variaatiokerroin (keskihajonta / keskiarvo x 100) oli tiloilla 1 - 41 \% välillä. Kuiva-ainepitoisuuden variaatiokerroin oli jäännösrehulaitteissa keskimäärin $8 \%$ ja linjaston tyhjäävissä laitteissa keskimäärin $19 \%(\mathrm{P}<0,01)$. Liemirehujen kuivaainepitoisuuden vaihtelu oli samansuuruista verrattuna kanadalaisen selvityksen tuloksiin (Braun ja de Lange 2004). Liemirehujen kuiva-ainepitoisuus laski linjaston loppua kohti putkiston tyhjentävissä laitteissa ja ero tavoitellun ja mitatun kuiva-ainepitoisuuden välillä suureni (kuvio 2). Suurimmillaan linjasto alku- ja loppupään venttiilien kuiva-ainepitoisuuden ero oli 10 \%-yksikköä, ja viimeisiltä venttiileiltä tulevassa rehussa oli vain $10-15 \%$ kuiva-ainetta. Tiloilla ongelma oli hyvin tiedostettu ja koneen jälkiä korjattiin jakamalla emakoille lisärehua käsin.

Jos emakon rehuannosta ei lisätä tai emakolle ei anneta lisärehua, liemen liian matala kuivaainepitoisuus voi hidastaa tiineen emakon kuntoutumista seuraavaa porsimista varten tai johtaa imettävän emakon liialliseen laihtumiseen liiallisen laihtumisen, mikä vaikutta myöhempään porsastuotokseen (Lawlor ja Lynch 2007, Schenkel ym. 2010). Liemen ollessa hyvin vetistä, ensimmäisen kerran porsineilla emakoilla syöntikykykin voi tulla vastaan. Emakon rehuseoksen kuiva-aine- ja ravintoainepitoisuuksien 
satunnaisen vaihtelun vaikutuksesta emakoiden kuntoon ja porsastuotokseen ei löytynyt julkaistuja tutkimuksia. Lihasioilla rehuseosten koostumusvaihtelujen vaikutuksia on tutkittu ja kompensatorisen kasvukyvyn vuoksi rehuseoksen valkuais- ja aminohappopitoisuuden vaihtelu ei välttämättä näy tuotantotuloksissa (Edmonds ja Bakker 2010).

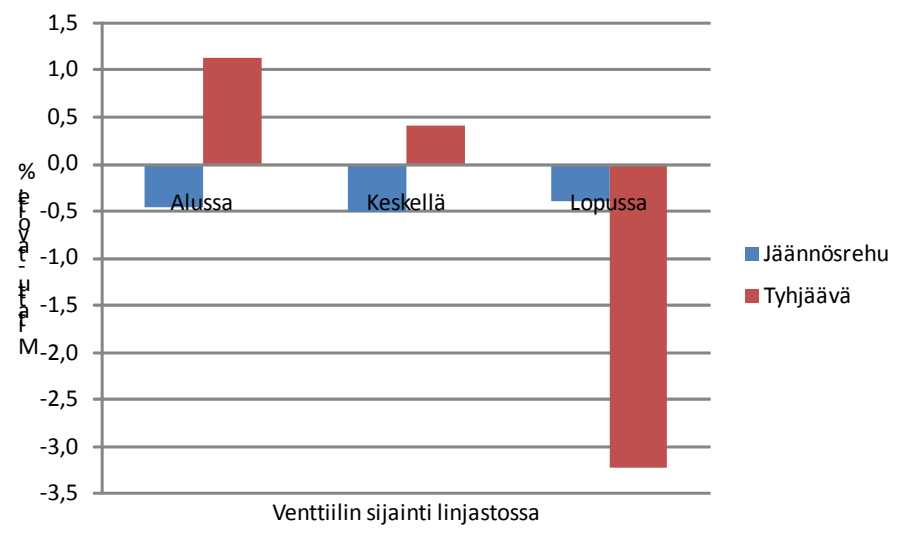

Kuvio 2. Liemirehuseosten mitatun kuiva-ainepitoisuuden ja ruokintalaitteeseen asetetun tavoitepitoisuuden ero linjaston eri osissa.

Liemen kuiva-aineen ravintoainepitoisuuksissa ei ollut linjaston eri osien välillä merkitseviä eroja kalsiumpitoisuutta lukuun ottamatta. Viljassa on vähän kalsiumia suhteessa fosforiin (MTT 2001) ja suuri osa sikojen rehuseosten sisältämästä kalsiumista on peräisin rehuseoksissa käytettävästä ruokintakalkista. Kalsiumia tulee seokseen myös monokalsiumfosfaatista. Kalsiumpitoisuuden vaihtelu muuttaa myös kalsiumin ja fosforin suhdetta, millä voi olla vaikutusta niin fosforin sulavuuteen kuin kalsiumin ja fosforin hyväksikäyttöön luuston. Emakoiden rehuissa kalsiumin ja fosforin suhteen tulisi olla 1,2 - 1,6 välillä (MTT 2011).

Taulukko 3. Tiineiden ja imettävien emakoiden liemirehujen kuiva-aineen koostumus toimintaperiaatteelta erilaisissa liemiruokintalaitteissa ja rehunjakolinjaston eri osissa.

\begin{tabular}{|c|c|c|c|c|c|c|c|c|c|}
\hline & \multicolumn{2}{|c|}{ Rehuseos } & \multirow[b]{2}{*}{$\mathrm{P}$} & \multicolumn{2}{|l|}{ Laitetyyppi } & \multicolumn{3}{|c|}{ Venttiilin paikka } & \multirow[b]{2}{*}{$\mathrm{P}$} \\
\hline & Imettävät & Tiineet & & Jäännösrehu & Tyhjäävä & $\mathrm{P}$ & Alussa & Lopussa & \\
\hline Raaka- & & & & & & & & & \\
\hline valkuainen, g/kg ka & $196,2(3,1)$ & $170,0(3,2)$ & $* * *$ & $181,7(3,0)$ & $184,5(3,3)$ & & $182,2(2,4)$ & $184,0(2,4)$ & \\
\hline Tuhka, g/kg ka & $63,0(2,6)$ & $53,8(2,7)$ & $*$ & $63,1(2,5)$ & $53,7(2,8)$ & $*$ & $59,2(1,9)$ & $57,7(1,9)$ & \\
\hline Kalsium, g/kg ka & $9,6(0,5)$ & $7,6(0,6)$ & $*$ & $9,7(0,5)$ & $7,4(0,6)$ & $* *$ & $9,0(0,4)$ & $8,2(0,4)$ & $*$ \\
\hline Fosfori, g/kg ka & $7,3(0,3)$ & $6,5(0,3)$ & 0,07 & $7,2(0,3)$ & $6,6(0,3)$ & & $6,9(0,2)$ & $6,9(0,2)$ & \\
\hline Ca:P & $1: 31(0,04)$ & $1,15(0,04)$ & $*$ & $1,34(0,04)$ & $1,12(0,04)$ & $* *$ & $1,28(0,04)$ & $1,17(0,04)$ & * \\
\hline Natrium, g/kg ka & $3,1(0,3)$ & $2,7(0,3)$ & & $3,1(0,3)$ & $2,7(0,3)$ & & $2,9(0,2)$ & $2,9(0,2)$ & \\
\hline Sinkki, mg/kg ka & $150(10)$ & 133 (19) & & 137 (19) & $146(10)$ & & $144(7)$ & $139(7)$ & \\
\hline
\end{tabular}

Linjaston loppua kohti laskevan kuiva-ainepitoisuuden vuoksi vesipesulinjastojen viimeisten venttiilien rehunäytteissä oli tuorepainoa kohti selvästi vähemmän valkuaista ja kivennäisaineita kuin jäännösrehullisten laitteiden liemissä (taulukko 4). Valkuaisen osalta muutos oli noin $30 \%$ linjaston alun ja lopun välillä. Jostain syystä putkiston tyhjentävissä laitteissa rehua eteenpäin työntävä vesipatsas näytti sekoittuvan erilailla erilaisiin liemiin. Veden ja liemirehun sekoittumiseen vaikuttaa liemen tilavuuspaino eli kuinka pitkälle matkalle putkistossa rehupatsas jakautuu. Rehun ominaispainon muuttuessa laitetta on säädettävä, jotta rehua eteenpäin työntävä vesipatsas ehdi sekoittua rehuun ennen viimeisiä venttiilejä, eikä ylijäämäsäiliöön joudu liian paljon rehua. 
Taulukko 4. Tiineiden ja imettävien emakoiden liemirehujen koostumus (tuorepainossa) jäännösrehullisissa ja putkiston tyhjäävien laitteistojen rehunjakolinjaston eri osissa.

\begin{tabular}{|c|c|c|c|c|c|c|c|c|}
\hline & \multicolumn{2}{|l|}{ Liemirehu (R) } & \multirow{2}{*}{$\begin{array}{l}\mathrm{R} \\
P \\
\end{array}$} & \multirow{2}{*}{$\begin{array}{l}\text { Laite- } \\
\text { tyyppi (T) }\end{array}$} & \multicolumn{2}{|c|}{ Venttiilin paikka (P) } & \multirow[b]{2}{*}{ Lopussa } & \multirow{2}{*}{$\begin{array}{c}\mathrm{PxT} \\
P \\
\end{array}$} \\
\hline & Imettävät & Tiineet & & & Alussa & Keskellä & & \\
\hline \multirow[t]{2}{*}{ Kuiva-aine, \% } & $24,1(0,60)$ & $21,4(0,61)$ & $* * *$ & Jäännösrehu & $25,4(0,75) \mathrm{c}$ & $25,3(0,79) \mathrm{c}$ & $25,4(0,75) \mathrm{c}$ & $* *$ \\
\hline & & & & Tyhjäävä & $21,8(0,80) b$ & $21,1(0,80) b$ & $17,5(0,80) a$ & \\
\hline \multirow[t]{2}{*}{ Raakavalk., g/kg } & $47(1,6)$ & $36(1,7)$ & $* * *$ & Jäännösrehu & $46(2,0) \mathrm{c}$ & & $41(2,0) b$ & $*$ \\
\hline & & & & Tyhjäävä & $46(2,0) \mathrm{C}$ & & $33(2,0) a$ & \\
\hline \multirow[t]{2}{*}{ Tuhka, g/kg } & $16(1,0)$ & $11(1,0)$ & * & Jäännösrehu & $16(2,0) \mathrm{c}$ & & $16(1,0) \mathrm{c}$ & $*$ \\
\hline & & & & Tyhjäävä & $12(1,1) b$ & & $9(1,1) \mathrm{a}$ & \\
\hline \multirow[t]{2}{*}{ Kalsium, g/kg } & $2,38(0,20)$ & $1,63(0,20)$ & * & Jäännösrehu & $2,58(0,20)$ & & $2,45(0,20)$ & $* *$ \\
\hline & & & & Tyhjäävä & $1,77(0,22)$ & & $1,23(0,22)$ & \\
\hline \multirow[t]{2}{*}{ Fosfori, g/kg } & $1,78(0,10)$ & $1,38(0,10)$ & $*$ & Jäännösrehu & $1,85(0,11)$ & & $1,84(0,11)$ & $* *$ \\
\hline & & & & Tyhjäävä & $1,46(0,11)$ & & $1,17(0,11)$ & \\
\hline \multirow[t]{2}{*}{ Ca:P } & $1,31(0,04)$ & $1,15(0,04)$ & $* *$ & Jäännösrehu & $1,36(0,05)$ & & $1,31(0,05)$ & \\
\hline & & & & Tyhjäävä & $1,20(0,05)$ & & $1,03(0,05)$ & \\
\hline \multirow[t]{2}{*}{ Natrium, g/kg } & $0,75(0,09)$ & $0,55(0,09)$ & & Jäännösrehu & $0,77(0,09)$ & & $0,78(0,09)$ & $*$ \\
\hline & & & & Tyhjäävä & $0,58(0,10)$ & & $0,47(0,10)$ & \\
\hline \multirow[t]{2}{*}{ Sinkki, g/kg } & $36,7(3,0)$ & $27,6(3,1)$ & $*$ & Jäännösrehu & $35,9(3,1)$ & & $34,6(3,1)$ & $*$ \\
\hline & & & & Tyhjäävä & $32,6(3,3)$ & & $25,4(3,3)$ & \\
\hline
\end{tabular}

\section{Johtopäätökset}

Tiineiden ja imettävien emakoiden liemet olivat koostumukseltaan erilaisia, ja pääsääntöisesti emakot saivat tuotantovaiheeseen sopivaa lientä. Jäännösrehuputkistojen liemissä oli terve maitohappokäyminen ja alempi pH kuin pestävien putkistojen liemissä. Jäännösrehuputkistot jakoivat varsin tasalaatuista seosta linjaston eri osissa. Sen sijaan putkiston tyhjäävien laitteiden liemen kuiva-ainepitoisuus laski linjaston loppua kohti, ja mitatun ja tavoitellun kuiva-ainepitoisuuden välinen ero suureni. Liemirehujen kuivaaineen valkuaispitoisuus pysyi samanlaisena linjaston alussa ja lopussa. Laskevan kuiva-ainepitoisuuden vuoksi vesipesulinjastojen loppupään liemissä oli lähes 30 \% vähemmän valkuaista kuin jäännösrehullisten laitteiden liemissä. Kuiva-ainepitoisuuden lasku johtuu tyhjentävissä putkistoissa rehua eteenpäin työntävän vesipatsaan sekoittumisesta rehuun. Kivennäisaineista kalsiumin pitoisuus vaihtelee liemirehuissa fosforipitoisuutta enemmän, ja ruokintakalkin lajittuminen voi johtaa emakon kannalta epäedulliseen kalsium-fosforisuhteeseen rehunjakolinjaston eri osissa.

\section{Kirjallisuus}

AOAC. 1990. Official Methods of Analysis. Association of Official Analytical Chemists, Arlington, VA. $1298 \mathrm{~s}$. Braun, K. \& de Lange, K. 2004. Liquid swine feed ingredients: nutritional quality and contaminants. $17 \mathrm{~s}$. www.slfa.ca

Canibe, N., Pedersen, A.Ø., Jensen, B.B. \& Jespersen, L. 2010. Microbiological and biochemical characterization of fermented liquid feed samples from 40 Danish farms. Livestock Science 134: 158 - 161.

Cumby, T.R. 1986. Design requirements of liquid feeding systems for pigs: a review. Journal of Agricultural Engineering Research 34: 153-172.

de Lange, C.F.M., Zhu, H.C., Niven, S., Columbus, D. \& Woods, D. 2006. Swine liquid feeding: nutritional consideration. 13 s. www.slfa.ca

Edmonds, M.S. \& Baker, D.H. 2010. Effect of dietary protein and lysine fluctuations in the absence and presence of ractopamine on performance and carcass quality of late-finishing pigs. Journal of Animal Science 88: 604 -611. European Food Safety Authority (EFSA). 2006. Opinion of the scientific panel on biological hazards on the request from the Commission related to the public health risks of feeding farmed animals with ready to use dairy products without further treatment. EFSA J. 340:1-58.

Gori, K., Bjørklund, M.K., Canibe, N., Pedersen, A.Ø. \& Jespersen, L. 2011. Occurrence and identification of yeast species in fermented liquid feed for piglets. Microbial Ecology 61: 146-153. 
Haacker, K., Block, H.J. \& Weissbach, F. 1983. Zur kolorimetrischen Milchsäurebestimmung in Silagen mit pHydroxydiphenyl. [On the colorimetric determination of lactic acid in silages with p-hydroxydiphenyl]. Archiv für Tierernährung, 33: 505-512.

Hurst, D., Clarke, L. \& Lean, I.J. 2008. Effect of liquid feeding at different water-to-feed ratios on the growth performance of growing-finishing pigs. Animal 2: 1297-1302.

Lawlor, P.G. \& Lynch, P.B. 2007. A review of factors influencing litter size in Irish sows. Irish Veterinary Journal 50: 359-366.

Luh Huang, C.-Y. \& Schulte, E.E. 1985. Digestion of plant tissue for analysis by ICP emission spectrometry. Communications in Soil Science and Plant Analysis 16: 943-958.

Missotten, J.A.M., Michiels, J., Ovyn, A., De Smet, S. \& Dierik, N.A. 2010. Fermented liquid feeds for pigs. Archives of Animal Nutrition 64: 437 - 466.

MTT. 2011. Rehutaulukot ja ruokintasuositukset. www.mtt.fi/rehutaulukot.

Plumed-Ferrer, C., Llopis, M., Hyvönen, P. \& von Wright, A. 2004. Characterization of the microbial community and its changes in liquid piglet feed formulations. 84: 1315-1318.

Plumed-Ferrer, C. \& von Wright, A. 2011. Antimicrobial activity of weak acids in liquid feed fermentations, and its effects on yeast and lactic acid bacteria. Journal of the Science of Food and Agriculture 91: 1032-1040.

Schenkel, A.C., Bernardi, M.L., Bortolozzo, F.P. \& Wentz, I. 2010. Body reserve mobilization during lactation in first parity sows and its effect on second litter size. 132: 165-172.

Siljander-Rasi, H. \& Valaja, J. 2008. Kuivaamaton perunaproteiini lihasikojen rehuna. Maataloustieteen Päivät 2008. Maataloustieteellisen Seuran tiedotteita 23, 6 s. http://www.smts.fi/mpol2008/index_tiedostot/Esitelmat/ es092.pdf

Valaja, J. 1998. Nutritive value of wet barley by-products from the integrted starch-ethanol process for pigs. Väitöstyö, Helsingin yliopisto. 55 s. Yliopistopaino. 